\title{
Nutrient accumulation on seedless watermelon
}

\section{Acúmulo de nutrientes em melancia sem sementes}

\section{Aparecido Alécio SCHIAVON JÚNIOR ${ }^{1}$; Leilson Costa GRANGEIRO²; Valdívia de Fátima Lima SOUSA $^{3}$; Antonia Rosimeire da Cruz SILVA ${ }^{4}$; Rafaella Rayane Macedo de LUCENA ${ }^{5}$}

${ }^{1}$ Mestre em Produção Vegetal, Syngenta Seeds Ltda. alecio.schiavon@symgenta.com.
${ }^{2}$ Autor para correspondência. Doutor em produção Vegetal, Universidade Federal Rural do Semi-Árido, Departamento de
Ciências Vegetais, Av. Francisco Mota, 572 - Bairro Costa e Silva, Mossoró-RN, CEP.59.625-900. leilson@ufersa.edu.br
${ }^{3}$ Doutoranda em Fitotecnia, Universidade Federal Rural do Semi-Árido - valdivia_sousa@hotmail.com
${ }^{4}$ Doutora em Fitotecnia, Universidade Federal Rural do Semi-Árido. agro_meirinha@hotmail.com
${ }^{5}$ Doutora em Fitotecnia, Universidade Federal Rural do Semi-Árido. rafaellarayane@hotmail.com

Recebido em: 21-12-2016; Aceito em: 06-03-2017

\begin{abstract}
The growth and nutrient accumulation, respectively represented by the dry mass accumulation and the nutrient absorption rate, offer essential information on plant nutrition and fertilization studies. With the aim of define the dry mass accumulation and the nutrient absorption rate for the seedless watermelon hybrid Master, an experiment was developed at Experimental Farm "Rafael Fernandes", which belongs to University Federal Rural do Semi-Árido, Mossoró, Rio Grande do Norte state, Brazil. The experimental design was randomized blocks, with seven treatments, constituted by the evaluation times: 14, 21, 28, 35, 42 and 49 days after transplantation (DAT), and four replications. The growth of the Master seedless watermelon plant was slow up to 21 DAT. The estimated dry mass accumulation at the end of the cycle was $361.11 \mathrm{~g} \mathrm{plant}^{-1}$, from this total, the leaves and stem were responsible for $45.3 \%$, and the fruits for $54.7 \%$. The greatest nutrient demands occurred between 35 and 49 DAT, following this order of magnitude: $\mathrm{K}>\mathrm{N}>\mathrm{Ca}>\mathrm{Mg}>\mathrm{P}>\mathrm{Fe}>\mathrm{Zn}>\mathrm{Mn}>\mathrm{B}>\mathrm{Cu}$.
\end{abstract}

Additional keywords: Citrullus lanatus L.; dry mass; plant nutrition

\section{Resumo}

O crescimento e o acúmulo de nutrientes, respectivamente representados pelo acúmulo de massa seca e pela marcha de absorção de nutrientes, fornecem informações essenciais em estudos de nutrição e adubação de plantas. Com o objetivo de definir o acúmulo de massa seca e a taxa de absorção de nutrientes para a melancia sem sementes, híbrido Master, desenvolveu-se um experimento na Fazenda Experimental "Rafael Fernandes", pertencente à Universidade Federal Rural do Semiárido, Mossoró, Estado do Rio Grande do Norte, Brasil. O delineamento experimental foi o em blocos casualizados completos, com sete tratamentos, constituídos pelas épocas de avaliações: 14; 21; 28; 35; 42 e 49 dias após o transplantio (DAT), e quatro repetições. O crescimento da planta de melancia foi lento até os 21 DATs. O acúmulo de massa seca estimado no final do ciclo (49 DAT) foi de 361,11 g planta $^{-1}$; deste total, as folhas e o caule foram responsáveis por $45,3 \%$, e os frutos, por $54,7 \%$. As maiores demandas de nutrientes ocorreram entre 35 e 49 DAT, seguindo a ordem de grandeza: $\mathrm{K}>\mathrm{N}>\mathrm{Ca}>\mathrm{Mg}>\mathrm{P}>\mathrm{Fe}>\mathrm{Zn}>\mathrm{Mn}>\mathrm{B}>\mathrm{Cu}$.

Palavras-chave adicionais: Citrullus lanatus L.; massa seca; nutrição de plantas.

\section{Introduction}

The states of Rio Grande do Norte and Ceará together have produced in 2015 a volume of $150,478 t$ of watermelon fruits on an area of 5,864 ha, representing $7.1 \%$ of the production and $6.1 \%$ of the watermelon planted area in Brazil (IBGE, 2015). From this area, approximately 1,000 ha were used for seedless watermelon from the "Personal size" type, whose fruits are characterized by for their small size (1 to $5 \mathrm{~kg}$ ), with or without seeds, and with high sugar content. These states are also the main exporters, and they are responsible for over $93 \%$ of the exports of this fruit.

The seedless watermelon production in Brazil is still incipient, although some small commercial areas have been implanted in different producing regions. The smaller size of the fruit, which is a characteristic that facilitates its transportation and storage, and the seedless fruit, which is commercially explored by the companies as a market innovation, are the main aspects that contribute to for an expanded crop. However, the major obstacle regarding the growth of the cultivated area in the country is the lack of technical information, above all, related to crop nutrition and fertilization.

The absorption curves of certain nutrients for some cucurbit species have shown a similar performance, where the nutrient accumulation follows the same dry mass accumulation curve standard, usually showing three different phases: on the first phase, the absorption is slow, followed by an intense absorption until it reaches the maximal point, from which a small declination occurs (Teixeira et al., 2014). 
In Brazil, studies have been published regarding the nutrient absorption rate on seedless watermelons conducted by Grangeiro \& Cecílio Filho (2004; 2005a; 2005b) and Teixeira et al. (2014); and on seeded watermelon, conducted by Vidigal et al. (2009), Lucena et al. (2011) and Almeida et al. (2012); however, it is observed that there are few studies regarding seedless watermelons, and the existing ones in the literature are not updated, or are conducted with different cultivars. Hence, there is the need to broaden this knowledge area evaluating the new materials that are being inserted on the market.

The fertilization recommendations, in turn, are based on studies regarding responses to fertilization and on the nutritional demand of the crop. Mainly due to the maximal absorption peak of the plant, the nutrient demand of the crops may not be inferred only by the total extraction. It is necessary to study the nutrient absorption rate according to time, in order to estimate how and when to apply the fertilizer, and how much of it should be used. Another factor that must be considered is that, in these regions, several cultivars are used within each species; therefore, it is questioned whether all of these cultivars have the same nutrient accumulation standard on the plant. These particularities should be known in order to recommend a correct fertilization for each crop.

Within this context, the aim of this study was to define the dry mass accumulation and the nutrient absorption rate for the seedless watermelon crop for the Master hybrid.

\section{Material and methods}

The experiment was performed from September to November 2012, at the Experimental Farm Rafael Fernandes ( $5^{\circ} 03^{\prime} 37^{\prime \prime} \mathrm{S}$ and $37^{\circ} 23^{\prime} 50^{\prime \prime} \mathrm{W}$ and altitude of $72 \mathrm{~m}$ ), which belongs to the Universidade Federal Rural do Semi-Árido, in Mossoró, Rio Grande do Norte state, Brazil. The chemical soil analyses of the experimental area showed the following results: $\mathrm{pH}\left(\mathrm{H}_{2} \mathrm{O}\right)=7.0 ; \mathrm{P}$ (Mehlich) $=103.2 \mathrm{mg} \mathrm{dm}^{-3}$; $\mathrm{K}=144.1 \mathrm{mg} \mathrm{dm}^{-3} ; \mathrm{Na}=13.9 \mathrm{mg} \mathrm{dm}^{-3} ; \mathrm{Ca}=$ $=2.20 \mathrm{cmol}_{\mathrm{c}} \mathrm{dm}^{-3} ; \mathrm{Mg}=2.90 \mathrm{cmol}_{\mathrm{c} \mathrm{dm}} \mathrm{dm}^{-3} ; \mathrm{Al}=$ $=0.00 \mathrm{cmol}_{\mathrm{c} \mathrm{dm}}^{-3}$ and $\mathrm{H}+\mathrm{Al}=0.00 \mathrm{cmol}_{\mathrm{c} \mathrm{dm}} \mathrm{dm}^{-3}$.

The experimental design consisted of randomized blocks, with seven treatments and four replications. The treatments were constituted by the evaluation times: $14,21,28,35,42$ and 49 days after transplantation (DAT). The experimental unit consisted of 30 plants per plot.

The hybrid used was Master, with small seedless fruits of the company Syngenta Seeds, and the pollinizer was the Quetzale cultivar. The spacing used was $2.0 \times 0.4 \mathrm{~m}$, using three Master plants (seedless) and one Quetzale plant (pollinizer) on the planting line in an alternated manner. The buds were produced in polyethylene trays with 200 cells, and transplanted when they presented one permanent leaf.

The soil was prepared by plowing and harrowing, followed by furrowing at lines that were $2.0 \mathrm{~m}$ away from each other, with depth of $30 \mathrm{~cm}$, where the foundation fertilization was conducted based on the soil analysis using $48 \mathrm{~kg} \mathrm{ha}^{-1}$ of $\mathrm{N}, 192 \mathrm{~kg} \mathrm{ha}^{-1}$ of $\mathrm{P}_{2} \mathrm{O}_{5}$ and $96 \mathrm{~kg} \mathrm{ha}^{-1}$ of $\mathrm{K}_{2} \mathrm{O}$. The side dressing fertilizations were realized daily through the irrigation water, according to the need of the crop, applying, throughout the watermelon cicle, $99 \mathrm{~kg} \mathrm{ha}^{-1}$ of $\mathrm{N}, 63 \mathrm{~kg} \mathrm{ha}^{-1}$ of $\mathrm{P}_{2} \mathrm{O}_{5}$ and $128 \mathrm{~kg} \mathrm{ha}^{-1}$ of $\mathrm{K}_{2} \mathrm{O}, 24.6 \mathrm{~kg} \mathrm{ha}^{-1}$ of $\mathrm{CaO}$, and $6.0 \mathrm{~kg} \mathrm{ha}^{-1}$ of MgO (Table 1). The sources used urea, potassium nitrate, potassium chloride, calcium nitrate and magnesium sulfate.

Table 1 - Nutrients applied by fertigation along watermelon cycle, hybrid Master.

\begin{tabular}{cccccc}
\hline Períod & \multicolumn{5}{c}{ Amount applied $\left(\mathrm{kg} \mathrm{ha}^{-1}\right)$} \\
\cline { 2 - 6 } (DAT) & $\mathrm{N}$ & $\mathrm{P}_{2} \mathrm{O}_{5}$ & $\mathrm{~K}_{2} \mathrm{O}$ & $\mathrm{CaO}$ & $\mathrm{MgO}$ \\
\hline $0-7$ & 10.0 & 11.0 & 6.0 & 0.0 & 0.0 \\
$8-14$ & 12.2 & 8.0 & 8.1 & 0.0 & 0.6 \\
$15-21$ & 16.0 & 9.7 & 10.2 & 2.5 & 1.0 \\
$22-28$ & 9.3 & 15.0 & 8.5 & 6.5 & 0.5 \\
$29-35$ & 22.5 & 11.1 & 32.1 & 6.5 & 2.7 \\
$36-42$ & 20.0 & 8.2 & 40.8 & 6.5 & 1.2 \\
$43-49$ & 9.0 & 0.0 & 22.3 & 2.6 & 0.0 \\
\hline
\end{tabular}

The irrigation system used was dripping, constituted by a lateral line per plant row with a self-compensating dripper and average flow of $1.4 \mathrm{~L} \mathrm{~h}^{-1}, 0.40 \mathrm{~m}$ away from each other, on lines that were $2.0 \mathrm{~m}$ away from each other. The other crop treatments, such as weed, plague and disease management, were conducted according to the need of the crop.

At transplanting, five plants per replicate were sampled to determine the concentration of nutrients at time ' 0 '. Subsequently, tree plants per replicate were sampled for the first two samplings (21 and 28 DAT), because of the small size of the plants. But, for the subsequent samplings ( 35,42 and 49 DAT), two plants per replicate were used. The plants were harvested without roots (cut at the base of the stem), fractionated into leaves, stem + branches and fruits (when present), and washed once under running water with detergent and again with distilled water. The samples were dried in a forced-air circulation oven at $65^{\circ} \mathrm{C}$, until reaching constant mass, approximately 72 hours. The concentrations of $\mathrm{N}, \mathrm{P}, \mathrm{K}, \mathrm{Ca}, \mathrm{Mg}, \mathrm{B}, \mathrm{Cu}, \mathrm{Fe}, \mathrm{Mn}$ and $\mathrm{Zn}$ were determined according to Embrapa (2009). 
The results of the analyses provided the nutrient concentrations. In order to determine the amount of these accumulates on each plant fraction, the concentration was multiplied by the dry mass of the referred fraction, and the total plant accumulation was determined by the sum of the accumulation of the fractions for each nutrient.

All the determined characteristics were subjected to analysis of variance and regression analysis using the Tablecurve software (Jandel Scientific, 1991).

\section{Results and discussions}

The beginning of flowering occurred between 20 and 25 days after transplanting and the early fruiting between 30 and 35 days. The productivity of was $21.8 \mathrm{t}$ ha $^{-1}$ (considering the population of 9375 plants per hectare of hybrid Master). The number of fruits per plant of 2.1 with an average fresh mass of $1.13 \mathrm{~kg}$.

The watermelon plant growth, expressed by the dry mass accumulation throughout the cycle, was slow up to 21 DAT, intensifying from this day on. The maximal increment of the dry mass accumulation per plant occurred between 28 to 42 DAT, when the accumulation rate reached $18.5 \mathrm{~g}$ plant $^{-1} \mathrm{day}^{-1}$. The estimated dry mass accumulation at the end of the cycle was $361.11 \mathrm{~g} \mathrm{plant}^{-1}$ at 49 DAT (Figure $1 \mathrm{~A}$ ).

The vegetative part, represented by the leaves and stem, participated in $45.3 \%$ of the total accumulated by the plant. The greater dry mass increment on the vegetative part was verified within the period from 21 to 35 DAT, corresponding to $9.0 \mathrm{~g} \mathrm{plant}^{-1}$ day $^{-1}$. The dry mass accumulated by the fruits, determined from 35 DAT, was initially small, increasing rapidly according to their growth. At the end of the cycle, it was equivalent to $54.7 \%$ of the total dry mass, with an estimated value of $195.74 \mathrm{~g} \mathrm{plant}^{-1}$. The period that had a higher accumulation was from 35 to 42 DAT, showing an increase rate of $13.35 \mathrm{~g} \mathrm{plant}^{-1}$ day $^{-1}$ (Figure $1 \mathrm{~A}$ ).

The performance observed on this study with the Master hybrid was similar to the ones observed for the Tide (Grangeiro \& Cecílio Filho, 2004) and Nova (Grangeiro \& Cecílio Filho, 2005a) watermelon hybrids, where they showed dry mass accumulation rates in the fruits higher than the accumulation of the vegetative part. Although these studies have been conducted with different locations, cultivars and production systems, after the onset of the fructification phase, a sink strength change occurred on the plant, offering a greater translocation of carbohydrates and other leaf components to the fruits, as a result of the prevalence of the reproductive phase over the vegetative phase (Marschner, 1995).

The nutrient accumulation followed the dry mass accumulation curve standard by the plants, which was reduced up to 21 DAT, intensifying continuously from this day on until the end of the cycle. The Master hybrid accumulated $9.0 \mathrm{~g} \mathrm{plant}^{-1}$ of nitrogen $(\mathrm{N})$; the vegetative part (leaves + stem) was responsible for
$41.5 \%$ and the fruits for $58.5 \%$ of the accumulation. The greater demand occurred from 21 to 35 DAT, coinciding with the time in which a greater dry mass accumulation occurred on the plant (Figure 1B). According to Teixeira et al. (2014), this coincidence on the period with greater nitrogen demands and dry mass accumulation is due to the verified correlation between both characteristics.

The nitrogen accumulation on the vegetative part was reduced up to 21 DAT, when it reached $2.12 \mathrm{~g} \mathrm{plant}^{-1}$. From this day on, it was intensified, reaching the estimated maximum at 39 DAT, $4.78 \mathrm{~g} \mathrm{plant}^{-1}$. The greatest accumulation occurred during the period from 28 to 35 DAT. The fruits also accumulated nitrogen continuously, with the maximum estimated accumulation of $4.86 \mathrm{~g} \mathrm{plant}^{-1}$ upon harvesting (Figure 1B).

The nitrogen absorption is assimilated by the roots in order to meet the needs of the nitrogenous compounds on the plant. Since the nutrients absorbed by the roots are not enough to meet the growth needs of the fruits, nutrients are translocated from the leaves to the growing organs, and a quick senescence of the leaves occurs, favoring the increase of the nitrogen concentration on the fruits. This fact was also observed for the phosphorus and potassium accumulation (Lucena et al., 2011; Teixeira et al., 2014).

Nitrogen was the second most required nutrient by the Master watermelon hybrid, which accumulated $84.0 \mathrm{~kg} \mathrm{ha}^{-1}$ of this nutrient across its entire cycle, considering that $51.5 \%$ was accumulated from 21 to 35 DAT. This value corresponded to $57 \%$ of the total nitrogen applied (147 kg ha-1).

The amount of accumulated phosphorus $(\mathrm{P})$ on the plant reached a maximum estimated value of $1.24 \mathrm{~g} \mathrm{plant}^{-1}\left(12 \mathrm{~kg} \mathrm{ha}^{-1}\right)$ at 45 DAT. The greatest demand was observed during the period from 28 to 42 DAT, whose mean accumulation rate was $0.05 \mathrm{~g} \mathrm{plant}^{-1}$ day $^{-1}$. At $21 \mathrm{DAT}$, the Master hybrid had accumulated $18.3 \%$ of the total accumulated phosphorus on the plant; this value was $80.8 \%$ at 35 DAT. At the end of the cycle, the vegetative part and the fruits contributed, respectively, with 33.3 and $66.7 \%$ (Figure 1C).

Phosphorus accumulation by the Master hybrid (1.24 $\left.\mathrm{g} \mathrm{plant}^{-1}\right)$ was lower than the ones obtained with the Nova $\left(3.75 \mathrm{~g} \mathrm{plant}^{-1}\right)$ and Shadow (1.9 $\mathrm{g} \mathrm{plant}^{-1}$ ) hybrids (Grangeiro \& Cecílio Filho, 2005a and 2005b), despite the fact that they showed a similar performance, regarding the accumulation, times of greater demand and larger accumulated amount on the vegetative part in relation to the fruits.

Phosphorus was the macronutrient that was the least accumulated by the watermelon plant. This result, related to the demand for this nutrient, was similar to the ones obtained with Quetzale (Lucena et al., 2011) and Crimson Sweet cultivars (Almeida et al., 2012) and different from the estimations made by Grangeiro \& Cecílio Filho (2004) for the Tide watermelon hybrid. The amounts of phosphorus removed 
from the soil by vegetables are usually low, mainly in comparison to nitrogen and potassium. However, despite this seemingly low demand, the contents of this nutrient on the soil solution, as well as the speed in which it is replenished on the soil solution, are not enough to meet the needs of the crops. Consequently, the fertilizations offer a higher proportion of phosphorus for planting.
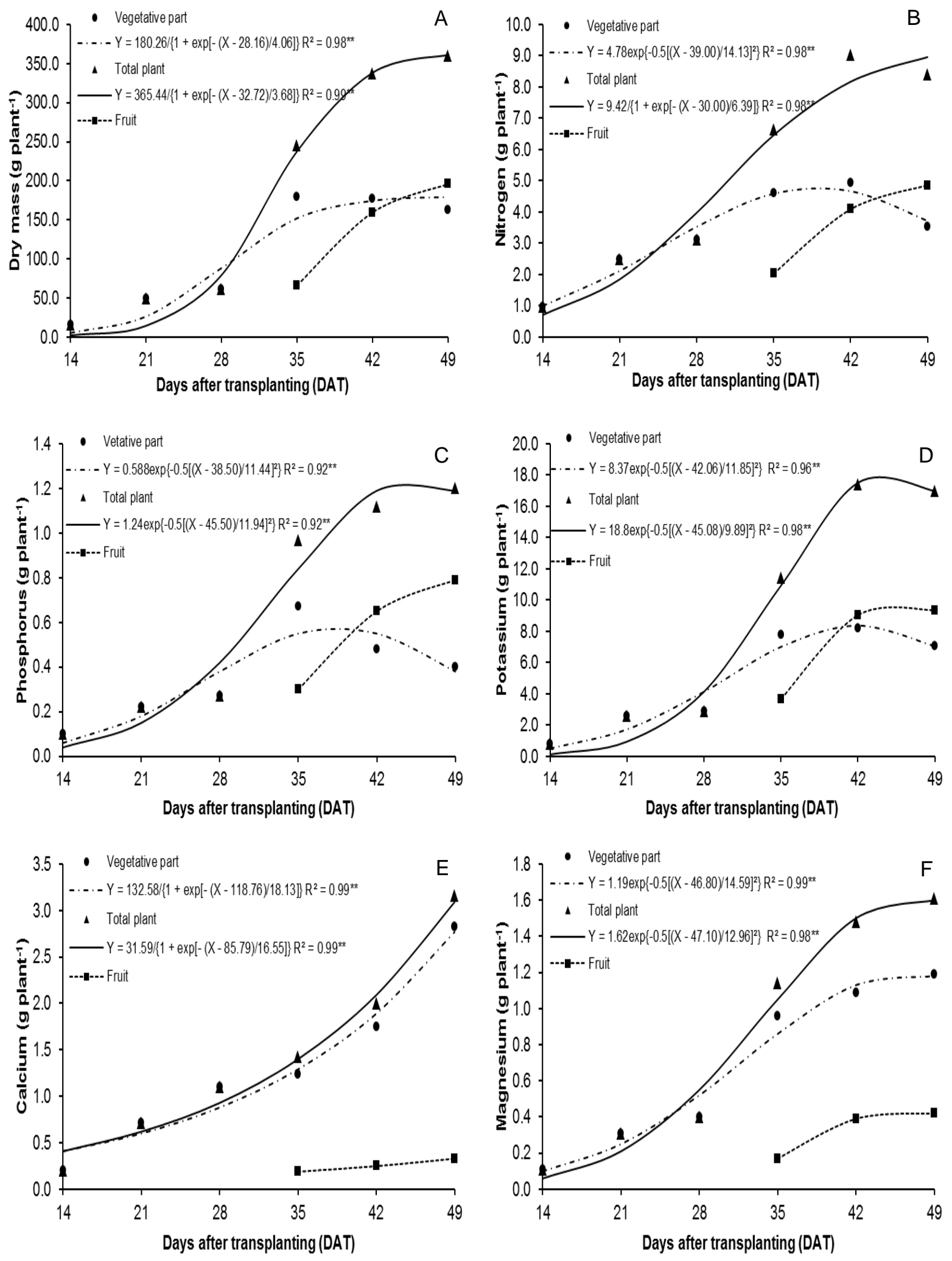

Figure 1 - Accumulation of dry mass (A), nitrogen (B), phosphorus (C), potassium (D), calcium (E) and magnesium ( $F$ ) on watermelons, Master hybrid, according to the days after transplanting. 
Potassium $(\mathrm{K})$ was the nutrient with the greatest accumulation, reaching the maximum of $18.4 \mathrm{~g}$ plant $^{-1}\left(172.5 \mathrm{~kg} \mathrm{ha}^{-1}\right)$, at 45 DAT, considering that the greatest demand occurred during the period from 28 to 42 DAT. The participations of the vegetative part and the fruits represented, respectively, 43.0 and $57.0 \%$. From 42 DAT on, the mean potassium accumulation on the vegetative part showed a small reduction. On the other hand, the fruits showed a strong increment, indicating the great potassium demand from the fruits (Figure 1D). The greater participation of fruits on the potassium content of the plant is in agreement with other studies found in the literature involving watermelons and melons (Zhu et al., 1996; Grangeiro \& Cecílio Filho, 2004).

According to Teixeira et al. (2014), the major importance of potassium on the formation of fruits is due to the significant relationship between the dry mass and the potassium content, which may be explained by the fact that potassium participates in the energetic functions of the plant, the translocation and storage of assimilates, and the water maintenance on the vegetable tissues, therefore, stimulating the growth and production of vegetables. Potassium is not part of any structure or organic molecules of the plant, such as nitrogen and phosphorus, which are ions that constitute proteins, nucleic acids, phospholipids, ATP, among others, but it plays important roles on plants, such as for their photosynthesis, enzymatic activation, protein synthesis and transportation of carbohydrates (Taiz \& Zeiger, 2004; Lucena et al., 2011).

Calcium $(\mathrm{Ca})$, the third most absorbed nutrient by the Master hybrid, reached the maximum accumulation of $3.1 \mathrm{~g} \mathrm{plant}^{-1}\left(29.1 \mathrm{~kg} \mathrm{ha}^{-1}\right)$ at 49 DAT, and the highest demand occurred on the period from 35 to 49 DAT (Figure 1E). Differently from what was observed for the previously-mentioned nutrients, the vegetative part was the one that accumulated the greatest amount of calcium, responsible for $89.0 \%$, while fruits were responsible for $11.0 \%$ of the accumulated total.

This calcium distribution on the plant is very common on vegetables with fruits and it is due to that fact that its transportation occurs virtually through xylem, through the transpiration current, favoring its accumulation on vegetative parts to the detriment of fruits. Another factor that may aggravate this situation is the competition between potassium and calcium, which occurs on the plant. The greater potassium flow for the watermelon fruit competes to reduce the presence of calcium on this organ of the plant (Malavolta et al., 1997; Teixeira et al., 2014).

Calcium is one of the most important nutrients for cucurbits, and it is associated to the formation of perfect flowers, the quality of the fruit and productivity. Another aspect that is largely studied is the relationship of calcium and the incidence of blossom-end rot (or black blossom-end), common on this family, mainly on watermelons. According to Linhares et al. (2007), the effects of calcium on the fruits have been mentioned. Applications of this cation produce positive effects to preserve the integrity and functionality of the cellular wall, maintaining the firm consistency of the fruit.

The accumulation of magnesium (Mg) occurred up to the end of the cycle, reaching an estimated maximum of $1.6 \mathrm{~g} \mathrm{plant}^{-1}\left(15.0 \mathrm{~kg} \mathrm{ha}^{-1}\right)$, at 49 DAT. The period with the greatest magnesium accumulation was from 28 to 42 DAT, showing a rate of $0.07 \mathrm{~g} \mathrm{plant}^{-1}$ day $^{-1}$, corresponding to $60.0 \%$ of the accumulated total (Figure 1F). Similarly to calcium, magnesium had a greater accumulation amount on the vegetative part (74.4\%) and lower accumulation amount on the fruits (25.6\%). This is very likely due to the fact that magnesium is part of the chlorophyll molecule. According to Marschner (1995), depending on the magnesium "status" on the plant, from 6 to $25 \%$ of the total magnesium may be related to the chlorophyll molecule, while other 5 to $10 \%$ are related to pectates on the cellular wall or deposited as soluble salt on the vesicle.

Magnesium was the fourth most accumulated nutrient by the Master watermelon hybrid. This result, related to the demand for this nutrient, was similar to the one obtained for the Quetzale hybrid (Lucena et al., 2011) and different to the Leopard hybrid (Teixeira et al., 2014), which accumulated more phosphorus than magnesium.

Regarding the studied micronutrients, iron (Fe) was the one with the highest accumulation by the Master watermelon hybrid. The iron accumulation rate was low during the first 21 DAT, intensifying from then on, reaching its maximum peak during the period from 28 to 35 DAT, when it reached $6.8 \mathrm{mg} \mathrm{plant}^{-1}$ day $^{-1}$. The total estimated accumulation for this nutrient was 107.6 mg plant $^{-1}$, obtained at 43 DAT (Figure 2A). The vegetative part contributed with the largest amount $(58.0 \%)$, in relation to the fruits $(42.0 \%)$.

This result was inferior to the one observed by Vidigal et al. (2009) for the Crimson Sweet watermelon, obtaining, at the end of the cycle, an accumulation of $194.7 \mathrm{mg} \mathrm{plant}^{-1}$ of Fe. According to Prado (2008), iron is important for the biosynthesis of chlorophyll, and it acts for the constitution and activation of important photosynthesis enzymes. Hence, it is likely that the increase on the demand for this micronutrient between 28 and 42 DAT is associated to its function during the photosynthesis and pigmentation process of branches leaves and fruits (Figure 2A).

Boron (B) was the fourth most accumulated micronutrient by the Master watermelon hybrid, with a percentage of $5.1 \%$ of the total accumulated micronutrients by the plant. The total accumulation increased until it reached $6.91 \mathrm{mg} \mathrm{plant}^{-1}$, at 45 DAT, which is equivalent to an immobilization of $64.8 \mathrm{~g} \mathrm{ha}^{-1}$ of $\mathrm{B}$. The maximum accumulation rate was $0.56 \mathrm{mg} \mathrm{plant}^{-1}$ day $^{-1}$ during the period from 28 to 35 DAT (Figure $2 \mathrm{~B}$ ). From the total accumulated on the plant, $49.4 \%$ were allocated on the vegetative part and $50.6 \%$, on the fruits. 

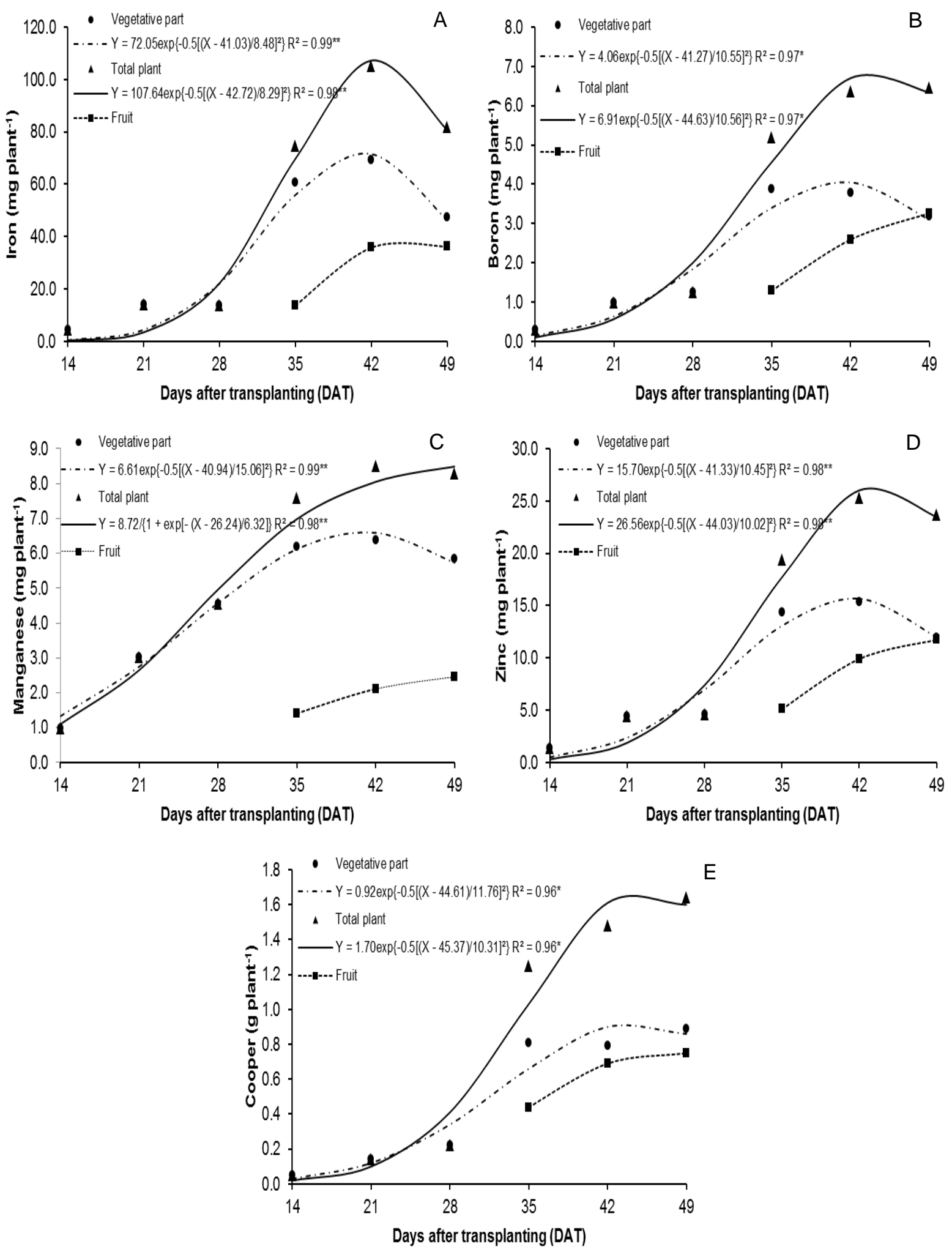

Figure 2 - Accumulation of iron (A), boron (B), manganese (C), zinc (D) and copper (E) on watermelons, Master hybrid, according to the days after transplanting.

Boron participates in the cellular growth, the biosynthesis of components from the cellular wall, the metabolism of phenols, nucleic acids, carbohydrates and IAA, in addition to conferring stability and structure to the cellular wall (Marschner, 1995; Taiz \& Zeiger, 2004).
Manganese (Mn) was the third most accumulated micronutrient by the Master watermelon, with a maximum value obtained at 49 DAT $\left(8.5 \mathrm{mg}\right.$ plant $\left.^{-1}\right)$, which is equivalent to an immobilization of $80 \mathrm{~g} \mathrm{ha}^{-1}$ of $\mathrm{Mn}$. From the total accumulated on the plant, $67.4 \%$ was allocated by the vegetative part and $32.6 \%$ by the 
fruits. The accumulation was gradual up to the end of the cycle, however, the highest demand occurred with the period from 21 to 35 DAT, when the accumulation rate was $0.31 \mathrm{mg} \mathrm{plant}^{-1}$ day $^{-1}$ (Figure $2 \mathrm{C}$ ).

Almeida et al. (2014), when evaluating the accumulation of micronutrients on the Crimson Sweet watermelon, verified that manganese was the third most demanded nutrient by the plant, similarly to this study. They also observed that the vegetative part $(90.89 \%)$ was the main compartment for the accumulation of manganese, followed by the fruits $(9.11 \%)$. The greater accumulation of this nutrient on the vegetative part was possibly due to the roles of the, manganese as an enzymatic activator and component on the photosynthesis and metabolism of nitrogen (Prado, 2008).

The accumulation of zinc ( $Z n)$ was also gradual up to the end of the cycle, reaching a maximum estimated accumulation of $15.7 \mathrm{mg} \mathrm{plant}^{-1}$ at 41 DAT, equivalent to an immobilization of $147.2 \mathrm{~g} \mathrm{ha}^{-1}$ of $\mathrm{Zn}$. The maximal accumulation rate was $1.33 \mathrm{mg} \mathrm{plant}^{-1}$ day $^{-1}$, obtained during the period from 28 to 42 DAT (Figure 2D). From the total zinc accumulated on the plant, $50.5 \%$ was allocated by the vegetative part and $49.5 \%$ by the fruits. Probably, the low mobility of zinc on the phloem had an influence so that the content of this nutrient on the vegetative part was not drastically reduced with the appearance of the fruits.

According to Epstein and Bloom (2006), zinc acts as a component and activator for several enzymes (dehydrogenases, proteinases, peptidases and phosphohydrogenase) and it is a precursor for the formation of auxins, RNA and ribosomes.

The maximal estimated copper accumulation (Cu) by the Master hybrid was $1.70 \mathrm{mg} \mathrm{plant}^{-1}$ at 45 DAT (16.0 $\left.\mathrm{g} \mathrm{ha}^{-1}\right)$. The greatest demand was observed on the period from 28 to 35 DAT, whose mean accumulation rate was $0.15 \mathrm{mg}$ plant $^{-1}$ day $^{-1}$. At 21 DAT, the Master hybrid had accumulated $3.0 \%$ of the total copper accumulated on the plant. This value was $76.2 \%$ at 35 DAT. At the end of the cycle, the vegetative part and the fruits contributed, respectively, with 54.0 and $46.0 \%$ (Figure 2E).

From all studied nutrients, copper was the one that was accumulated in the lowest quantity by the Master hybrid. This result obtained on this study was similar to the ones observed by Almeida et al. (2014) and Vidigal et al. (2009), both with the Crimson Sweet watermelon, in which copper was also the nutrient found at the lowest amounts on the plant.

In relation to the export of nutrients, at the harvesting time, 49 DAT, the fruits corresponded to $54.7 \%$ of the dry mass of the plant, $58.5 \%$ of $\mathrm{N} ; 66.7 \%$ of $\mathrm{P}$; $57.0 \%$ of $\mathrm{K} ; 11.0 \%$ of $\mathrm{Ca} ; 26.3 \%$ of $\mathrm{Mg} ; 42.0 \%$ of $\mathrm{Fe}$; $50.5 \%$ of $\mathrm{B} ; 32.6 \%$ of $\mathrm{Mn} ; 49.5 \%$ of $\mathrm{Zn}$ and $46.0 \%$ of $\mathrm{Cu}$. The number of fruits per plant was 2.1 with mean mass of $1.13 \mathrm{~kg}$.

For the plant population of 9375 plants ha-1 of the Master hybrid, the mean productivity was $21.8 \mathrm{t} \mathrm{ha}^{-1}$, considering that, at the end of the cycle, the amounts of macronutrients exported by the fruits in $\mathrm{kg} \mathrm{ha}^{-1}$ were: $45.6(\mathrm{~N}) ; 7.4(\mathrm{P}) ; 87.7(\mathrm{~K}) ; 3.1(\mathrm{Ca})$ and $4.0(\mathrm{Mg})$, and for micronutrients in $\mathrm{g} \mathrm{ha}^{-1}$ : $339.4(\mathrm{Fe}) ; 110.0(\mathrm{Zn})$; $23.10(\mathrm{Mn})$; $30.6(\mathrm{~B})$ and $7.0(\mathrm{Cu})$.

\section{Conclusions}

The growth of the Master seedless watermelon plant was slow up to 21 days after transplant. The estimated dry mass accumulation at the end of the cycle was $361.11 \mathrm{~g} \mathrm{plant}^{-1}$, from this total, the leaves and stem were responsible for $45.3 \%$, and the fruits for $54.7 \%$. The greatest nutrient demands occurred between 35 and 49 DAT, following this order of magnitude: $\mathrm{K}>\mathrm{N}>\mathrm{Ca}>\mathrm{Mg}>\mathrm{P}>\mathrm{Fe}>\mathrm{Zn}>\mathrm{Mn}>\mathrm{B}>\mathrm{Cu}$.

\section{References}

Almeida EIB, Corrêa MCM, Nóbrega GN, Pinheiro EAR, Lima, FF (2012) Crescimento e marcha de absorção de macronutrientes para a cultivar de melancia Crimson Sweet. Revista Agro@mbiente 6(3):205-214.

Almeida EIB, Nóbrega GN, Corrêa MCM, Pinheiro EAR, Araújo NA (2014) Crescimento e marcha de absorção de micronutrientes para a cultivar de melancia Crimson Sweet. Revista Agro@mbiente 8(1):74-80.

Embrapa (2009) Empresa Brasileira de Pesquisa Agropecuária. Embrapa Informação Tecnológica Manual de análises químicas de solos, plantas e fertilizantes. Brasília. 627 p.

Epstein E, Bloom AJ (2006) Nutrição mineral de plantas: princípios e perspectivas. Londrina. $416 \mathrm{p}$.

Grangeiro LC, Cecílio Filho AB (2004) Acúmulo e exportação de macronutrientes pelo híbrido de melancia Tide. Horticultura Brasileira, 22(1):93-97.

Grangeiro LC, Cecílio Filho AB (2005a) Acúmulo e exportação de nutrientes em melancia sem sementes. Horticultura Brasileira, 23(3):763-767.

Grangeiro LC, Cecílio Filho AB (2005b) Acúmulo e exportação de nutrientes pela melancia sem sementes, híbrido Shadow. Científica, 33(1):69-74.

IBGE - Instituto Brasileiro de Geografia e Estatística (2015) Estados/Culturas Temporárias/Melancia. Disponível em <http://www.ibge.gov.br/estadosat/>. Acesso em 10 jun. 2016.

Jandel Scientific. Table Curve: curve fitting software. Corte Madera, CA: Jandel Scientific, 1991.

Linhares LA, Santos CDS, Abreu CMP, Corrêa AD (2007) Transformações químicas, físicas e enzimáticas de goiabas "Pedro Sato" tratadas na pós-colheita com cloreto de cálcio e 1-metilciclopropeno e armazenadas sob refrigeração. Ciência e Agrotecnologia, 31(3):829-841. 
Lucena RRM, Negreiros MZ, Medeiros JF, Grangeiro LC, Marrocos STP (2011) Crescimento e acúmulo de macronutrientes em melancia 'Quetzale' cultivada sob diferentes níveis de salinidade da água de irrigação. Revista Caatinga, 24(1):34-42.

Malavolta E, Vitti GC, Oliveira SA (1997) Avaliação do estado nutricional das plantas: princípios e aplicações. Piracicaba, 319p.

Marschner H (1995) Mineral nutrition of higher plants. New York: Academic Press, 889 p.

Prado RM (2008) Nutrição de Plantas. São Paulo: UNESP/FUNESP, 2008. 408 p.
Teixeira MV, Oliveira CPM, Santos ML, Pintar AF, Oliveira FL (2014) Influência dos nutrientes na formação da massa seca da melancia sem sementes. Agropecuária. Científica no Semi-Árido, 10(3):31-40.

Taiz L, Zeiger E (2004) Fisiologia vegetal. Porto Alegre: Artmed, 722p.

Vidigal SM, Pacheco DD, Costa EL, Facion CE (2009) Crescimento e acúmulo de macro e micronutrientes pela melancia em solo arenoso. Revista Ceres, 56(1):112-118.

Zhu HX, Xiang Z, Alin S, Chunhe S (1996) Studies on the nutrient uptake and balance fertilization of watermelon. Acta Horticulturae Sinica, 23(2):145-149. 